\title{
Interaction of CD14 haplotypes and soluble CD14 on pulmonary function in agricultural workers
}

Tricia D. LeVan ${ }^{1,2^{*}}$, Lynette M. Smith³ ${ }^{3}$ Art J. Heires ${ }^{4}$, Ted R. Mikuls², Jane L. Meza ${ }^{3}$, Lisa A. Weissenburger-Moser ${ }^{1}$ and Debra J. Romberger ${ }^{2}$

\begin{abstract}
Background: Agricultural environments are contaminated with organic dusts containing bacterial components. Chronic inhalation of organic dusts is implicated in respiratory diseases. CD14 is a critical receptor for gram-negative lipopolysaccharide; however, its association with respiratory disease among agricultural workers is unknown. The objective of this study was to determine if serum soluble CD14 (sCD14) levels are associated with lung function among agricultural workers and if this association is modified by genetic variants in CD14.

Methods: This cross-sectional study included 584 veterans with $>2$ years of farming experience and that were between the ages of 40 and 80 years. Participants underwent spirometry and were genotyped for four tagging CD14 polymorphisms (CD14/-2838, rs2569193; CD14/-1720, rs2915863; CD14/-651, rs5744455; and CD14/-260, rs2569190). Serum sCD14 was assayed by ELISA.

Results: Subjects were $98 \%$ white males with a mean age 64.5 years. High soluble CD14 levels (> median SCD14) were associated decreased lung function ( $F E V_{1} / F V C, p=0.011 ; \%$ predicted $\mathrm{FEV}_{1}, p=0.03$ ). When stratified by COPD (yes/no) and smoking status (ever/never), high sCD14 levels (> median sCD14) were associated with low lung function among ever smokers with COPD (\% predicted $\mathrm{FEV}_{1}, \mathrm{p}_{\mathrm{adj}}=0.0008 ; \mathrm{FEV} / \mathrm{FVC}, \mathrm{p}_{\mathrm{adj}}=0.0002$ ). A similar trend was observed for never smokers with COPD; however, results did not reach statistical significance due to small sample size. There was a significant SCD14 $\times$ COPD/smoking interaction with lung function (\% predicted FEV ${ }_{1}$, $p_{\text {inter }}=0.0498 ; F E V_{1} / F V C$, pinter $=0.011$ ). Regression models were adjusted for age, body mass index, education, sex, race and years worked on a farm. No association was found between CD14 polymorphisms/haplotypes (CD14/-2838; CD14/-1720; CD14/-651; CD14/-260) and sCD14 levels. The final model included the variables sCD14 and haplotypes and a haplotype x sCD14 interaction term. Individuals with the GTG haplotype (CD14/-2838 $\rightarrow$ CD14/-260) and high sCD14 levels (> median sCD14) had on average 6.94 lower \% predicted FEV ${ }_{1}$ than individuals with the GCCA haplotype and low sCD14 levels ( $\leq$ median sCD14, $p_{a d j}=0.03$ ).
\end{abstract}

Conclusion: CD14 haplotypes and SCD14 are important mediators of lung function among those with COPD in this occupationally-exposed population.

Keywords: CD14, Agriculture, Lung function, COPD, Polymorphism

\footnotetext{
* Correspondence: tlevan@unmc.edu

'Department of Epidemiology, University of Nebraska Medical Center,

985910, Omaha, NE 68198-5910, USA

${ }^{2}$ Department of Internal Medicine and Veterans Nebraska Western lowa

Healthcare System, Omaha, NE, USA

Full list of author information is available at the end of the article
} 


\section{Background}

CD14 is a pattern-recognition receptor and exists as two distinct forms: as a glycosyl-phosphatidylinositol (GPI) anchored membrane protein on the surface of monocytes, macrophages and neutrophils and as a monocyte or liverderived serum soluble protein (sCD14) lacking the GPI anchor [1]. Soluble CD14 is an acute phase protein [2], but is also found in normal serum at microgram concentrations [3], and confers sensitivity to a gram-negative bacterial cell wall component, i.e. lipopolysaccharide (LPS), for cells lacking membrane CD14, such as endothelial and epithelial cells [4]. Together with LPS and LPS-binding protein, CD14 forms a ligand that interacts with the tolllike receptor -4 (TLR-4)/MD-2 receptor complex and leads to activation of innate host defense mechanisms, stimulating numerous $\mathrm{Th}_{1}$ proinflammatory cytokines, including tumor necrosis factor- $\alpha$ (TNF- $\alpha)$ and interleukin6 (IL-6) [5]. Recently, it has been suggested that CD14 also can interact with other pathogen-associated molecular patterns (PAMPs) such as acylated lipoproteins and peptidioglycan from gram-positive bacteria, and can participate in the formation of multi-receptor complexes other than TLR-4, e.g. TLR-1, -2 and -6 [6].

Farming environments are highly contaminated with airborne inhalable organic dust [7, 8], which contains PAMPs, including gram-negative and gram-positive bacterial components $[9,10]$. Forty $\%$ of these dust particles are in the respirable range with a median diameter of $4 \mu \mathrm{m}$ or less, which may be deposited at the level of the terminal bronchioles and alveoli [7, 11]. Chronic inhalation of complex organic dust is implicated in respiratory disease development and severity, including rhinitis, sinusitis, asthma-like syndrome, organic dust toxic syndrome, chronic bronchitis, and chronic obstructive pulmonary disease (COPD) [12]. Several studies associate LPS levels in the agricultural environment with adverse respiratory health outcomes. In healthy individuals, inhalation of purified LPS induces dose-related symptoms, a decrease in lung function and diffusion capacity, airway obstruction and both bronchial and systemic inflammation [13-17].

While these studies suggest an important role of LPS in respiratory disease pathogenesis, the function of sCD14, a critical receptor for LPS, in host defense and respiratory disease among agricultural workers has not been defined. In fact, no large-scale comprehensive studies have examined the relationship of SCD14 concentrations with measures of lung function in occupationally- or nonoccupationally- exposed individuals. The limited numbers of small studies in non-occupationally exposed adults have shown that sCD14 levels are elevated in ever smokers and COPD patients (LPS is a component of cigarette smoke), and humans experimentally exposed to LPS compared to healthy non-smokers $[14,18]$.
Soluble CD14 levels also have been shown to be influenced by $C D 14$ polymorphisms in diverse populations such as infants, patients with cardiovascular disease, tuberculosis, periodontal disease and healthy persons $[14,19-23]$. Whether the association between sCD14 levels and lung function is modified by CD14 polymorphisms has not been investigated.

As part of the present study, we utilized cross-sectional data from a well-characterized population of agricultural workers from the Midwest to determine if sCD14 concentration was associated with lung function. We hypothesized that circulating concentrations of SCD14 are elevated in agricultural workers with impaired lung function compared to those with higher lung function. We also examined whether well-characterized polymorphisms and haplotypes in the CD14 gene modify this association.

\section{Methods}

\section{Study population and clinical assessments}

This is a cross-sectional study of U.S veterans with agricultural exposure recruited from the outpatient clinics at the Omaha Veterans Affairs Medical Center. During a clinic visit, the veteran was asked the following question, "Have you worked on a farm for more than two years?"

Those who answered "yes" to this question and were between the ages of 40 and 80 years of age were eligible for the study. Based on self-report and medical chart confirmation, participants had no history of asthma, lung cancer, metastatic cancer to the lungs or interstitial lung diseases such pulmonary fibrosis, sarcoidosis or hypersensitivity pneumonitis. Atopy was not assessed in the participants. Those with a history of an infection or exacerbation within the previous three weeks were excluded from the study. Recruitment into the study began March 2008 and continued through December 2013, with a total 681 participants. Demographic information, smoking status and years worked on a farm were obtained by self-report at the time of enrollment. Smokers were defined as having smoked more than 100 cigarettes in their lifetime [24]. Blood was obtained by venipuncture and used for cell differentials, serum sCD14 and genomic DNA isolation. All participants underwent spirometry with post-bronchodilator spirometry $(0.083 \%$ albuterol $)$ performed on veterans with a $\mathrm{FEV}_{1} / \mathrm{FVC}<0.70$. COPD was defined by the Global Initiative for Chronic Obstructive Lung Disease (GOLD) classification criteria as $\mathrm{FEV}_{1} / \mathrm{FVC}<0.70$ [25]. The highest recorded $\mathrm{FEV}_{1}$ and $\mathrm{FVC}$ were used to derive height-, weight-, age-, gender- and ethnic- adjusted values based on National Health and Nutrition Survey (NHANESIII) reference equations [26]. The study was approved by the VA Institutional Review Board, and all participants signed a written informed consent document before enrollment. 


\section{Soluble CD14 ELISA}

Soluble CD14 in serum was quantified using a commercially available kit (DuoSet ELISA development system, $\mathrm{R}$ \& D Systems, Inc., Minneapolis, MN, USA) (Supplement Methods). The limit of detectability was $125 \mathrm{pg} / \mathrm{ml}$.

\section{Genetic analysis}

The complete coding region of $C D 14$, intronic sequence, $6 \mathrm{~kb}$ of 5' genomic and $2 \mathrm{~kb}$ of 3' genomic DNA were analyzed, and tagging single nucleotide polymorphisms (SNPs) were chosen based on a minor allele frequency > $5 \%$ and linkage disequilibrium (LD) $<0.8$ [27]. Additional SNPs were included based on their functional significance and relevant citations in the literature. The following SNPs were analyzed for this study, nomenclature relative to translation start site: CD14/-2838, rs2569193; CD14/1720, rs2915863; CD14/-651, rs5744455; and CD14/-260, rs2569190. Aliases relative to the transcription start site are CD14/-2737, CD14/-1619, CD14/-550, and CD14/159 , respectively. Genomic DNA was isolated from whole blood using the QiaAMP DNA Blood and Tissue Mini Kit (Qiagen, Valencia, CA, USA). DNA samples were genotyped using matrix-assisted laser desorption/ionization time-of-flight mass spectrometry (MALDI-TOF; Agena Bioscience, San Diego, CA, USA). Multiplex polymerase chain reaction assays and associated extension reactions were designed using SpectroDesigner software (Agena Bioscience). Primer extension products were loaded onto a 384-element chip with a nanoliter pipetting system (Agena Bioscience) and analyzed with a MassArray mass spectrometer (Bruker Daltonik GmbH, Bremen, Germany). The resulting mass spectra were analyzed for peak identification using SpectroTyperRT 4.0 software. For genotyping quality control, Hardy-Weinberg calculations were performed to ensure that each marker was within the expected allelic population equilibrium.

\section{Statistical analyses}

Continuous lung function variables (\% predicted $\mathrm{FEV}_{1}$ and $\mathrm{FEV}_{1} / \mathrm{FVC}$ ratio) were compared by patient characteristics using $t$-test and ANOVA. Soluble CD14 levels were categorized at the median value ( $\leq$ median, $>$ median) due to right-handed skew and bimodal distribution; therefore, a transformation would not be able to normalize the data. Because of the bimodal distribution, we felt it most appropriate to categorize soluble CD14 at the median. Associations with patient characteristics and lung function variables were assessed using chi-square and t-tests. Because smoking history and COPD are directly related to lung function, a combination variable (COPDsmoke) was made to assess the interaction between sCD14 and lung function. COPDsmoke contained 4 categories: 1) COPD, ever smoker, 2) COPD, never smoker, 3) no COPD, ever smoker, and 4) no COPD, never smoker. The effect of sCD14 ( $\leq$ median, > median) and COPDsmoke on lung function was examined in 2-way ANOVA models, with the lung function variable as the outcome, fixed effects for sCD14 ( $\leq$ median, > median) and COPDsmoke, and the $\mathrm{sCD} 14$ ( $\leq$ median, > median) $\mathrm{x}$ COPDsmoke interaction term included in the model. Multivariable linear regression models were examined considering the sCD14 ( $\leq$ median, $>$ median) $x$ COPDsmoke interaction on lung function, while adjusting for age, body mass index (BMI), education, sex, race and years worked on a farm. P-values for pairwise comparisons were adjusted with Tukey's method, a standard technique that considers all possible pairwise differences of means at the same time.

Associations between sCD14 ( $\leq$ median, $>$ median) and CD14 polymorphisms were assessed using chi-square tests. The effect of CD14 polymorphisms on lung function was assessed with univariate ANOVA and multivariable linear regression. Multiplicative interactions of CD14 polymorphisms $\mathrm{x}$ sCD14 ( $\leq$ median, > median) or CD14 polymorphisms $\mathrm{x}$ COPDsmoke on lung function were tested, and neither were found to be statistically significant. Multivariable models were adjusted for age, BMI, education, sex, COPD status, race and years worked on a farm.

CD14 haplotypes were constructed using Haploview software, and haplotype blocks were estimated using the confidence interval for $\mathrm{R}^{2}$ values. Haplotypes were defined as CD14/-2838, CD14/-1720, CD14/-651 and CD14/-260. The association between sCD14 and CD14 haplotypes was tested using the $\mathrm{R}$ function haplo.score. The effect of a multiplicative interaction of $\mathrm{SCD} 14$ ( $\leq$ median, $>$ median) $\mathrm{x} C D 14$ haplotypes on lung function was also evaluated in regression models, assuming an additive model for the haplotypes. The interaction between COPDsmoke x CD14 haplotypes was not significant and removed from the models. Modelling the effect of haplotypes was conducted with the $\mathrm{R}$ package haplo.stats and the haplo.glm and haplo.score functions. Haplo.glm fits multivariable linear regressions of lung function on haplotype, allowing for ambiguous haplotypes, interactions and covariates. This method performs an iterative two-step expectationmaximization (EM) algorithm, with the posterior probabilities as weights to update the regression coefficients, and the regression coefficients are used to update the posterior probabilities. Models that do not include haplotype information were fit using SAS 9.3 (SAS Institute Inc., Cary, NC, USA).

\section{Results}

\section{Subject characteristics}

Study population characteristics stratified by lung function (\% predicted $\mathrm{FEV}_{1}$ and $\% \mathrm{FEV}_{1} / \mathrm{FVC}$ ) are summarized in Table 1. There were a total of 681 veterans in the 
Table 1 Characteristics of study population by lung function

\begin{tabular}{|c|c|c|c|}
\hline & Total N & $\begin{array}{l}\mathrm{FEV}_{1}(\% \text { predicted) } \\
\text { Mean (SD) }\end{array}$ & $\begin{array}{l}\mathrm{FEV}_{1} / \mathrm{FVC}(\%) \\
\text { Mean (SD) }\end{array}$ \\
\hline \multicolumn{4}{|l|}{ Age, years } \\
\hline $39-50$ & 38 & $87.6(11.8)$ & $74.2(7.1)$ \\
\hline $51-60$ & 117 & 80.8 (18.8) & $71.4(10.9)$ \\
\hline $61-70$ & 274 & 80.2 (21.6) & $70.3(11.7)$ \\
\hline $71-80$ & 155 & $77.0(23.3)$ & $66.0(12.2)$ \\
\hline \multicolumn{4}{|l|}{ Sex } \\
\hline Male & 571 & $79.6(21.2)$ & $69.4(11.7)$ \\
\hline Female & 13 & $92.3(14.1)$ & $77.3(6.1)$ \\
\hline \multicolumn{4}{|l|}{ BMI } \\
\hline$<25$ & 86 & 72.4 (25.9) & $61.8(14.9)$ \\
\hline $25-29.9$ & 171 & $81.3(22.2)$ & $68.5(11.7)$ \\
\hline$\geq 30$ & 327 & $81.2(18.8)$ & $72.3(9.5)$ \\
\hline \multicolumn{4}{|l|}{ Race } \\
\hline White & 555 & $79.8(21.1)$ & $69.6(11.7)$ \\
\hline Other & 23 & 87.7 (20.9) & $71.8(9.0)$ \\
\hline \multicolumn{4}{|l|}{ Education } \\
\hline$\leq$ High School & 250 & $77.0(22.3)$ & 67.3 (12.6) \\
\hline > High School & 311 & 82.8 (19.6) & $71.4(10.3)$ \\
\hline \multicolumn{4}{|l|}{ Smoking Status } \\
\hline Ever & 463 & 77.9 (21.4) & $68.3(12.1)$ \\
\hline Never & 113 & 88.5 (16.6) & $75.2(6.6)$ \\
\hline \multicolumn{4}{|l|}{ COPD } \\
\hline No & 354 & 88.6 (16.6) & $76.6(4.3)$ \\
\hline Yes & 230 & $66.6(20.5)$ & $58.9(11.3)$ \\
\hline \multicolumn{4}{|c|}{ Steroid Use (Inhaled, Oral) ${ }^{a}$} \\
\hline No & 507 & 83.4 (18.9) & $71.6(9.7)$ \\
\hline Yes & 77 & $56.6(20.8)$ & $57.0(15.2$ \\
\hline \multicolumn{4}{|c|}{ Worked on a Farm, years } \\
\hline$<10$ & 93 & 76.7 (20.9) & $69.5(11.8)$ \\
\hline 10-19.9 & 158 & $83.1(18.8)$ & $70.7(10.3)$ \\
\hline 20-29.9 & 92 & $79.0(21.5)$ & $68.9(12.1)$ \\
\hline $30+$ & 228 & $79.5(22.5)$ & $69.3(12.2)$ \\
\hline \multicolumn{4}{|l|}{ Exposure to crops } \\
\hline No & 70 & $77.4(22.4)$ & $68.9(12.0)$ \\
\hline Yes & 499 & $80.4(20.9)$ & $69.8(11.5)$ \\
\hline \multicolumn{4}{|c|}{ Exposure to animals } \\
\hline No & 63 & $77.0(22.2)$ & $70.4(12.0)$ \\
\hline Yes & 506 & $80.4(21.0)$ & $69.6(11.5)$ \\
\hline
\end{tabular}

Abbreviations and Definitions: BMI body mass index $\left(\mathrm{kg} / \mathrm{m}^{2}\right), F E V_{1}$ forced expiratory volume in $1 \mathrm{~s}, \% \mathrm{FEV}_{1} / \mathrm{FVC} \mathrm{FEV} / \mathrm{FVC} \times 100$, FVC forced vital capacity, COPD FEV $1 / F V C<0.70$

aln the last 12 months have you taken inhaled steroids (yes/no), Advair (yes/no) or Prednisone (yes/no)? population; however, only 584 patients had complete data on pulmonary function measures and covariates. Those with missing data were excluded in the analysis. Individuals with missing data had similar demographics (age, BMI, education, sex, race, smoking status, COPD and mean years worked on a farm) compared to those included in the analysis (data not shown). Reflecting demographic trends of the VA population in the urban Midwest [28], patients were predominately white males (98\%) with a mean age of 64.8 years. The population included $230 \mathrm{pa}-$ tients with COPD, as defined by $\mathrm{FEV}_{1} / \mathrm{FVC}<0.70$, and 354 without $C O P D$. Individuals with low pulmonary function values (\% $\mathrm{FEV}_{1}$ and $\% \mathrm{FEV}_{1} / \mathrm{FVC}$ ) were more likely to be older, have lower BMI, have less education, and be ever smokers. Lung function values were independent of years worked on a farm, exposure to crops, and exposure to animals.

\section{Risk factors associated with $\mathrm{SCD} 14$ concentration}

Soluble CD14 levels were categorized as $\leq$ median or $>$ median. Age and BMI were determinants of sCD14 levels (Table 2). The mean age for participants with sCD14 levels $>$ median was greater (66.0 years) compared to those with sCD14 levels $\leq$ median (63.6 years) $(p=0.0057)$. Individuals with BMI less than $30 \mathrm{~kg} / \mathrm{m}^{2}$ were more likely to have $\mathrm{sCD} 14$ levels $>$ median than those with a $\mathrm{BMI} \geq 30 \mathrm{~kg} / \mathrm{m}^{2} \quad(p=0.01)$. Surprisingly, none of the farming variables (years worked on a farm, exposure to crops, exposure to animals) were statistically associated with sCD14 levels.

\section{Association of sCD14 levels with lung function}

Because impaired lung function has been shown to be associated with systemic inflammation and CD14 is a pivotal receptor for PAMPs found in agricultural dusts, we investigated the association between serum sCD14 levels and pulmonary function among agricultural workers. In univariate models we found that there was an association between sCD14 concentration and the lung function variables $\mathrm{FEV}_{1}$ (\% predicted, $p=0.03$ ) and $\mathrm{FEV}_{1} / \mathrm{FVC}(\%, 0.011)$ (Table 2). In regression models we included a sCD14 x COPDsmoke multiplicative interaction term because COPD and smoking status are related to lung function. We found statistically significant interactions with $\%$ predicted $\mathrm{FEV}_{1}\left(\mathrm{p}_{\text {inter }}=0.020\right)$ and $\%$ $\mathrm{FEV}_{1} / \mathrm{FVC}$ ( $\mathrm{p}_{\text {inter }}=0.0033$ ) in the unadjusted analysis, which remained significant after adjusting for covariates (Fig. 1). Individuals with low \% predicted $\mathrm{FEV}_{1}$ or \% $\mathrm{FEV}_{1} / \mathrm{FVC}$ and $>$ median $\mathrm{sCD} 14$ levels were more likely to be ever/never smokers with COPD compared to those without COPD.

In a stratified analysis of COPD status and smoking status, we found an inverse relationship between sCD14 levels and lung function among those with COPD 
Table 2 Risk Factors Associated with Serum sCD14 Concentration

\begin{tabular}{|c|c|c|c|}
\hline & $\begin{array}{l}\text { sCD14 } \leq \text { median } \\
(n=292) \\
N(\%)\end{array}$ & $\begin{array}{l}\text { sCD14 > median } \\
(n=292) \\
N(\%)\end{array}$ & $\overline{p \text {-value }}$ \\
\hline \multicolumn{4}{|l|}{ Age, years } \\
\hline $39-50$ & $22(8 \%)$ & $16(5 \%)$ & \multirow[t]{4}{*}{0.0057} \\
\hline $51-60$ & $70(24 \%)$ & 47 (16\%) & \\
\hline $61-70$ & $139(48 \%)$ & 135 (46\%) & \\
\hline $71-80$ & $61(21 \%)$ & $94(32 \%)$ & \\
\hline \multicolumn{4}{|l|}{ Sex } \\
\hline Male & 283 (97\%) & 288 (99\%) & \multirow[t]{2}{*}{0.16} \\
\hline Female & $9(3 \%)$ & $4(1 \%)$ & \\
\hline \multicolumn{4}{|l|}{ BMI } \\
\hline$<25$ & $34(12 \%)$ & $52(18 \%)$ & \multirow[t]{3}{*}{0.01} \\
\hline $25-29.9$ & 77 (26\%) & $94(32 \%)$ & \\
\hline$\geq 30$ & $181(62 \%)$ & $146(50 \%)$ & \\
\hline \multicolumn{4}{|l|}{ Race } \\
\hline White & 275 (95\%) & $280(97 \%)$ & \multirow[t]{2}{*}{0.29} \\
\hline Other & $14(5 \%)$ & $9(3 \%)$ & \\
\hline \multicolumn{4}{|l|}{ Education } \\
\hline$\leq$ High School & 118 (42\%) & $132(48 \%)$ & \multirow[t]{2}{*}{0.15} \\
\hline > High School & $166(58 \%)$ & $145(52 \%)$ & \\
\hline \multicolumn{4}{|l|}{ Smoking Status } \\
\hline Ever & $225(78 \%)$ & $238(83 \%)$ & \multirow[t]{2}{*}{0.13} \\
\hline Never & $64(22 \%)$ & 49 (17\%) & \\
\hline \multicolumn{4}{|l|}{ COPD } \\
\hline No & $181(62 \%)$ & 173 (59\%) & \multirow[t]{2}{*}{0.50} \\
\hline Yes & $111(38 \%)$ & $119(41 \%)$ & \\
\hline \multicolumn{4}{|c|}{ Steroid Use (Inhaled, Oral) ${ }^{\mathrm{a}}$} \\
\hline No & $260(89 \%)$ & 247 (85\%) & \multirow[t]{2}{*}{0.11} \\
\hline Yes & $32(11 \%)$ & $45(15 \%)$ & \\
\hline $\mathrm{FEV}_{1} / \mathrm{FVC}($ mean $\pm \mathrm{SD})$ & $70.9 \pm 10.1$ & $68.4 \pm 13.0$ & 0.011 \\
\hline $\mathrm{FEV}_{1}(\%)($ mean $\pm \mathrm{SD})$ & $81.8 \pm 19.4$ & $78.0 \pm 22.6$ & 0.030 \\
\hline \multicolumn{4}{|l|}{ Worked on a Farm, years } \\
\hline$<10$ & $48(17 \%)$ & $45(16 \%)$ & \multirow[t]{4}{*}{0.23} \\
\hline 10-19.9 & $81(28 \%)$ & 77 (27\%) & \\
\hline 20-29.9 & $54(19 \%)$ & $38(13 \%)$ & \\
\hline $30+$ & $105(36 \%)$ & $123(43 \%)$ & \\
\hline \multicolumn{4}{|l|}{ Exposure to crops } \\
\hline No & $31(11 \%)$ & $39(14 \%)$ & \multirow[t]{2}{*}{0.26} \\
\hline Yes & 257 (89\%) & $242(86 \%)$ & \\
\hline \multicolumn{4}{|l|}{ Exposure to animals } \\
\hline No & $25(9 \%)$ & $38(14 \%)$ & \multirow[t]{2}{*}{0.06} \\
\hline Yes & 263 (91\%) & 243 (86\%) & \\
\hline
\end{tabular}

Abbreviations and Definitions: $B M I$ body mass index $\left(\mathrm{kg} / \mathrm{m}^{2}\right)$, COPD, $\mathrm{FEV}_{1} / \mathrm{FVC}<0.70$

${ }^{\mathrm{a}}$ In the last 12 months have you taken inhaled steroids (yes/no), Advair (yes/no) or Prednisone (yes/no)?

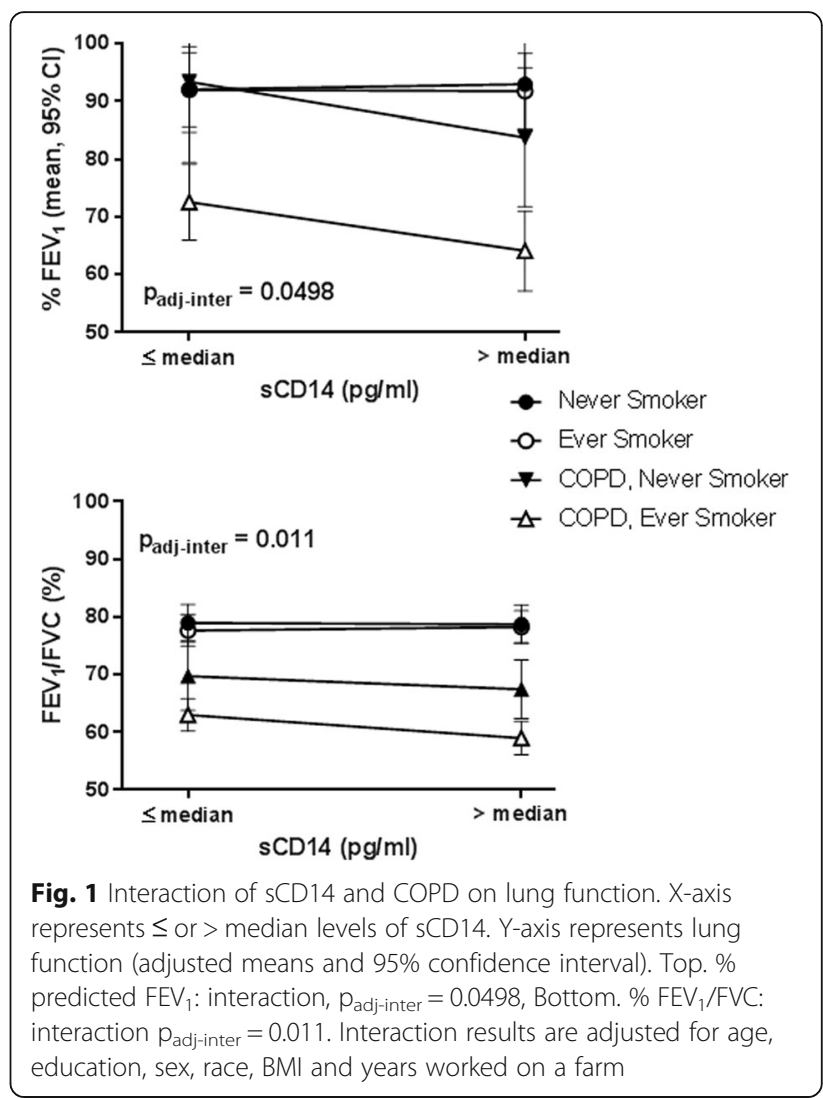

(Table 3). Among the ever smokers with COPD, there were statistically significant associations with \% predicted $\mathrm{FEV}_{1}\left(\mathrm{p}_{\mathrm{adj}}=0.0008\right)$ and $\% \mathrm{FEV}_{1} / \mathrm{FVC}$ ( $\mathrm{p}_{\text {adj }}=$ 0.0002). We found a similar trend for never smokers with COPD; however, our sample size was too small to make statistical inferences. No association between sCD14 levels and lung function measures among those without COPD was observed (Table 3). Similar results were observed when stratifying by COPD status (yes/no) (Additional file 1: Table S1) or the following three categories: COPD; no COPD, current smoker; no COPD, never or former smoker (Additional file 1: Table S2).

\section{Association of CD14 polymorphisms and haplotypes with sCD14 levels}

The study population was genotyped for four polymorphisms at locations $-2838,-1720,-651$, and -260 relative to the translation start site. The observed minor allele frequencies for the polymorphisms (CD14/-2838, $\mathrm{A}=25.7 \%$; CD14/-651, $\mathrm{T}=22.9 \%$; CD14/-260, $\mathrm{A}=49.4 \%$; CD14/$1720, C=42.0 \%)$ showed no deviation from a population in Hardy-Weinberg equilibrium $(p>0.05)$ and were consistent with frequencies reported from the HapMap Project (http:/www.ncbi.nlm.nih.gov/SNP/index.html) in individuals with Northern and Western European ancestry (data not shown). Call rate for all polymorphisms was 
Table 3 Association of Soluble CD14 Levels with FEV 1 \& FEV 1 /FVC: Stratified by COPD and Smoking Status

\begin{tabular}{|c|c|c|c|c|c|c|c|c|}
\hline \multicolumn{9}{|c|}{$F E V_{1}(\%$ predicted $)$} \\
\hline \multirow[b]{2}{*}{ sCD14 } & \multicolumn{2}{|c|}{ COPD, Ever Smoker } & \multicolumn{2}{|c|}{ COPD, Never smoker } & \multicolumn{2}{|c|}{ No COPD, Ever Smoker } & \multicolumn{2}{|c|}{ No COPD, Never Smoker } \\
\hline & $n$ & Mean \pm SE & $n$ & Mean \pm SE & $n$ & Mean \pm SE & $n$ & Mean \pm SE \\
\hline$\leq$ Median & 104 & $69.8 \pm 1.7$ & 7 & $91.2 \pm 6.7$ & 121 & $88.2 \pm 1.6$ & 57 & $89.1 \pm 2.3$ \\
\hline \multirow[t]{3}{*}{ > Median } & 104 & $60.9 \pm 1.7$ & 12 & $78.0 \pm 5.1$ & 134 & $87.9 \pm 1.5$ & 37 & $90.6 \pm 2.9$ \\
\hline & $\mathrm{p}$ & 0.0003 & $p$ & 0.12 & $p$ & 0.88 & $\mathrm{p}$ & 0.69 \\
\hline & ${ }^{a} p_{a d j}$ & 0.0008 & ${ }^{a} p_{a d j}$ & 0.26 & ${ }^{a} p_{a d j}$ & 0.91 & ${ }^{\mathrm{a}} \mathrm{p}_{\mathrm{adj}}$ & 0.81 \\
\hline \multicolumn{9}{|l|}{$\%$ FEV $_{1} /$ FVC } \\
\hline sCD14 & $n$ & Mean \pm SE & $n$ & Mean \pm SE & $n$ & Mean \pm SE & $n$ & Mean \pm SE \\
\hline$\leq$ Median & 104 & $61.0 \pm 0.74$ & 7 & $67.0 \pm 2.9$ & 121 & $76.3 \pm 0.7$ & 57 & $77.6 \pm 1.0$ \\
\hline \multirow[t]{3}{*}{ > Median } & 104 & $56.0 \pm 0.74$ & 12 & $62.9 \pm 2.2$ & 134 & $76.3 \pm 0.7$ & 37 & $77.0 \pm 1.2$ \\
\hline & $\mathrm{p}$ & $<0.0001$ & $\mathrm{p}$ & 0.26 & $\mathrm{p}$ & 0.93 & $p$ & 0.73 \\
\hline & ${ }^{a} p_{a d j}$ & 0.0002 & ${ }^{\mathrm{a}} \mathrm{p}_{\text {adj }}$ & 0.53 & ${ }^{\mathrm{a}} \mathrm{p}_{\text {adj }}$ & 0.52 & ${ }^{a} p_{a d j}$ & 0.86 \\
\hline
\end{tabular}

Abbreviations and Definitions: sCD14, soluble CD14; FEV 1 , forced expiratory volume in $1 \mathrm{~s} ; \% \mathrm{FEV}_{1} / \mathrm{FVC}$ FEV 1 /FVC $\times 100$; FVC, forced vital capacity; COPD, FEV 1 /FVC $<0.70$; ever smokers, current and former smokers

${ }^{a}$ Multivariable results $\left(p_{\text {adj }}\right)$ are adjusted for age, body mass index, education, sex, race and years worked on a farm

$P$-values adjusted for multiple comparisons with Tukey's method

greater than 95\%. The pairwise LD between the four polymorphisms was $\mathrm{r} 2<0.8$ (Additional file 2: Figure S1). Five haplotypes were identified in the population, and their estimated frequencies were $40.6 \%$ for GCCA (-2838, $-1720,-651,-260), 26.9 \%$ for ATCG, 23.4\% for GTTG, $7.2 \%$ for GTCA and $1.8 \%$ for other. We did not find an association between $C D 14$ polymorphisms (CD14/-2838, $p=0.47 ; C D 14 /-1720, p=0.53 ; C D 14 /-651, p=0.46$; $C D 14 /-260, p=0.96$; $)$ or haplotypes $(p=0.31)$ with sCD14 levels ( $\leq$ median or $>$ median) in the univariate or multivariable analysis $(n=584$; data not shown).

\section{Association of CD14 polymorphisms and haplotypes with lung function}

We found no significant association between CD14 polymorphisms and lung function (Table 4). In contrast, we found that the haplotype GTCA was significantly associated with \% $\mathrm{FEV}_{1} / \mathrm{FVC}$ even after adjustment for covariates ( $\mathrm{p}_{\mathrm{adj}}=0.021$ ). Individuals with the GTCA haplotype had lower $\mathrm{FEV}_{1} / \mathrm{FVC}$ than those with the GCCA haplotype. There was no association of CD14 haplotypes with \% predicted $\mathrm{FEV}_{1}$ (Table 4). We did not find a significant interaction between the COPDsmoke $\mathrm{x}$ CD14 haplotypes on lung function (data not shown).

Analyses were then conducted to examine the $\mathrm{sCD} 14 \mathrm{x}$ haplotype interaction in relation to $\%$ predicted $\mathrm{FEV}_{1}$ or $\%$ $\mathrm{FEV}_{1} / \mathrm{FVC}$ (Table 5). There was a significant interaction between the GTTG haplotype and sCD14 for \% predicted $\mathrm{FEV}_{1}$. Individuals with this haplotype and sCD14 levels > median, have on average, 6.94 lower \% predicted $\mathrm{FEV}_{1}$ values than individuals who possess the GCCA haplotype and $\mathrm{sCD} 14$ levels $\leq$ median ( $\mathrm{p}_{\text {inter }}=0.015$ ). Evidence of interaction was also observed for the GTCA haplotype, though of borderline significance $\left(p_{\text {inter }}=0.061\right)$. Individuals with the GTCA haplotype and > median levels of sCD14 have increased $\mathrm{FEV}_{1} / \mathrm{FVC}$ values than those with the GTCA haplotype and $\leq$ sCD14 levels.

\section{Discussion}

CD14 is an acute phase protein involved in LPS signaling and therefore is essential for interfacing the innate immune system with PAMPs. Studies have found that airway inflammation and decreased pulmonary function are common among farmers, and these findings are linked to the presence of LPS in inhaled organic dust [12]. The importance of CD14 in inflammatory processes is underscored by its association with a multitude of diseases, including sepsis, cardiovascular disease, periodontitis, tuberculosis and atopic asthma [29-33]. CD14 represents an important mediator of lung function, as we have shown previously that CD14 haplotypes (CD14/-1720G or CD14/-260A) are associated with decreased lung function among those exposed to agricultural environments [34]. The current study presents new evidence for the relationship between sCD14 levels and pulmonary function among agricultural workers and haplotype $\mathrm{x}$ sCD14 interaction with lung function.

Specifically we found that $\mathrm{sCD} 14$ levels were inversely related to \% predicted $\mathrm{FEV}_{1}$ and $\mathrm{FEV}_{1} / \mathrm{FVC}$; however, this association was found only in COPD patients that were ever smokers compared to those without COPD (ever/never smokers). Though there have been no studies investigating the association between sCD14 levels and lung function, in a case-control study of nine never smokers, 10 healthy smokers and 10 COPD patients, Reguiro et al. showed that SCD14 levels in the bronchoalveolar lavage fluid were elevated among healthy smokers and patients with COPD compared to never-smokers [18]. 
Table 4 Association of CD14 Polymorphisms and Haplotypes with FEV 1 \& FEV 1 /FVC

\begin{tabular}{|c|c|c|c|c|c|c|c|}
\hline CD14 Genotype & $\mathrm{n}$ & $\begin{array}{l}\mathrm{FEV}_{1}(\% \text { Predicted }) \\
\text { Mean } \pm \mathrm{SD}\end{array}$ & $p$ & ${ }^{a} p_{a d j}$ & $\begin{array}{l}\% \mathrm{FEV}_{1} / \mathrm{FVC} \\
\text { Mean } \pm \mathrm{SD}\end{array}$ & $p$ & ${ }^{a} p_{a d j}$ \\
\hline \multicolumn{8}{|c|}{ rs2569193 CD14/-2838 } \\
\hline AA & 35 & $78.3 \pm 18.4$ & 0.85 & 0.98 & $69.4 \pm 10.3$ & 0.97 & 0.64 \\
\hline$A G$ & 228 & $79.7 \pm 21.5$ & & & $69.5 \pm 12.3$ & & \\
\hline GG & 316 & $80.3 \pm 21.4$ & & & $69.7 \pm 11.4$ & & \\
\hline \multicolumn{8}{|c|}{ rs2915863 CD14/-1720 } \\
\hline CC & 90 & $80.7 \pm 21.7$ & 0.73 & 0.65 & $70.3 \pm 10.0$ & 0.20 & 0.13 \\
\hline $\mathrm{CT}$ & 293 & $80.3 \pm 20.7$ & & & $69.8 \pm 11.8$ & & \\
\hline$\Pi$ & 180 & $78.9 \pm 21.9$ & & & $68.6 \pm 12.2$ & & \\
\hline \multicolumn{8}{|c|}{ rs5744455 CD14/-651 } \\
\hline$\pi$ & 33 & $85.3 \pm 19.5$ & 0.12 & 0.071 & $72.9 \pm 8.3$ & 0.14 & 0.12 \\
\hline TC & 193 & $77.8 \pm 21.4$ & & & $68.6 \pm 12.5$ & & \\
\hline CC & 339 & $80.4 \pm 21.3$ & & & $69.7 \pm 11.6$ & & \\
\hline \multicolumn{8}{|c|}{ rs2569190 CD14/-260 } \\
\hline AA & 134 & $79.7 \pm 21.2$ & 0.71 & 0.97 & $70.1 \pm 11.4$ & 0.48 & 0.43 \\
\hline GA & 287 & $79.2 \pm 21.7$ & & & $69.1 \pm 12.2$ & & \\
\hline GG & 141 & $81.0 \pm 20.2$ & & & $70.4 \pm 11.0$ & & \\
\hline \multicolumn{8}{|l|}{ Haplotype $^{\text {b }}$} \\
\hline GCCA & $245^{c}$ & $81.2 \pm 1.7$ & Ref. $^{d}$ & Ref. & $71.0 \pm 1.0$ & Ref. & Ref \\
\hline ATCG & 149 & $79.9 \pm 1.3$ & 0.41 & 0.62 & $70.1 \pm 0.7$ & 0.28 & 0.20 \\
\hline GTTG & 134 & $80.7 \pm 1.4$ & 0.76 & 0.37 & $70.6 \pm 0.7$ & 0.61 & 0.38 \\
\hline GTCA & 44 & $76.4 \pm 2.3$ & 0.056 & 0.25 & $66.4 \pm 1.3$ & 0.001 & 0.021 \\
\hline Other & 12 & $90.5 \pm 3.7$ & 0.014 & 0.035 & $71.3 \pm 2.1$ & 0.89 & 0.81 \\
\hline
\end{tabular}

Abbreviations and Definitions: $F E V_{1}$ forced expiratory volume in $1 \mathrm{~s}, \% \mathrm{FEV}_{1} / \mathrm{FVC} \mathrm{FEV} / \mathrm{FVC} \times 100$; FVC, forced vital capacity

${ }^{\mathrm{a}}$ Multivariable results $\left(\mathrm{p}_{\mathrm{adj}}\right)$ are adjusted for age, BMl, education, sex, COPD status, race and years worked on a farm

${ }^{b}$ Haplotypes defined as -2838/-1720/-651/-260; Mean \pm SE

'Sample sizes estimated from haplotype frequency. Mean \pm SE are shown

${ }^{\mathrm{d}}$ Pairwise comparison to the Base haplotype

We found a similar but non statistically significant relationship in our agriculturally-exposed population. This discrepancy is most likely due to measurement of sCD14 levels in two different compartments, the bronchoalveolar lavage fluid of the lung and blood serum.

The reasons for the association between sCD14 concentration and reduced pulmonary function among those with COPD are not fully understood, but several mechanisms may be involved. Reduced lung function among COPD patients may be responsible, in part, for the observed systemic inflammation as measured by sCD14. Inflammatory lung or pulmonary epithelial cells have been shown to express IL-6. IL-6 may reach the liver via the bloodstream, stimulating the acute phase response and production of $\mathrm{sCD} 14$ by the liver and sequentially activating pulmonary inflammatory cells during transit through the pulmonary circulation. An alternative mechanism -reverse causation- cannot be excluded: high levels of cytokines and acute phase reactants in the peripheral circulation as a consequence of cigarette smoking may be a cause rather than a consequence of poor lung function. Persistence of elevated $\mathrm{sCD} 14$ concentration and systemic inflammation may result in damage to the airways, and lower $\mathrm{FEV}_{1}$ of COPD patients.

The marginal associations between CD14 genotypes and $\mathrm{sCD} 14$ concentrations may not be surprising, given the equivocal results reported to date. While some studies have shown significant association of the same tagging polymorphisms examined in our study with sCD14 concentration, others failed to show any associations $[14,19,20,35-38]$. These inconsistencies may be driven by the complex gene-environment interactions of CD14 expression as well as the use of relatively healthy versus diseased subjects where any genetic influences on SCD14 are simply overshadowed by other inflammatory stimuli. The masking of the polymorphism-protein signal via inflammation was convincingly reported by measuring sCD14 levels pre- and post- endotoxin inhalation; $C D 14 /-260$ and $C D 14 /-1720$ were associated with sCD14 levels pre-inhalation yet not post-inhalation [14]. Recently, it has been shown that the association 
Table 5 Interaction of sCD14 and CD14 haplotypes with lung function

\begin{tabular}{|c|c|c|c|c|}
\hline Variable & $\begin{array}{l}\mathrm{FEV}_{1} \\
\text { Base model } \\
(n=549)\end{array}$ & $\begin{array}{l}\text { FEV }_{1} \\
\text { Plus haplotypes } \\
(n=545)\end{array}$ & $\begin{array}{l}\mathrm{FEV}_{1} / \mathrm{FVC} \\
\text { Base model } \\
(n=549)\end{array}$ & $\begin{array}{l}\mathrm{FEV}_{1} / \mathrm{FVC} \\
\text { Plus haplotypes } \\
(n=545)\end{array}$ \\
\hline Age, yrs & $-0.09(0.10)$ & $-0.09(0.10)$ & $-0.07(0.04)$ & $-0.08(0.04)$ \\
\hline Body mass index, $\mathrm{kg} / \mathrm{m}^{3}$ & $-0.37(0.12)^{*}$ & $-0.34(0.12)^{*}$ & $0.14(0.05)^{*}$ & $0.14(0.05)^{*}$ \\
\hline \multicolumn{5}{|l|}{ Sex } \\
\hline Male & Referent & Referent & Referent & Referent \\
\hline Female & $6.17(5.11)$ & $6.79(5.14)$ & $4.39(2.17)^{*}$ & $4.55(2.18)^{*}$ \\
\hline \multicolumn{5}{|l|}{ Education } \\
\hline$\leq$ High School & Referent & Referent & Referent & Referent \\
\hline$>$ High School & $2.51(1.61)$ & $2.68(1.62)$ & $1.22(0.68)$ & $1.12(0.69)$ \\
\hline \multicolumn{5}{|l|}{ Race } \\
\hline White & Referent & Referent & Referent & Referent \\
\hline Other & $2.97(3.89)$ & $-2.52(4.42)$ & $0.78(1.65)$ & $0.23(1.89)$ \\
\hline Worked on Farm, yrs & $0.06(0.04)$ & $0.06(0.04)$ & $0.01(0.02)$ & $0.01(0.02)$ \\
\hline \multicolumn{5}{|l|}{ COPDSmoke } \\
\hline No COPD, Never smokers & Referent & Referent & Referent & Referent \\
\hline No COPD, Ever smokers & $0.01(2.24)$ & $-0.33(2.25)$ & $0.74(0.95)$ & $-0.84(0.96)$ \\
\hline COPD & $-22.03(2.3)^{*}$ & $-22.03(2.31)^{*}$ & $-17.13(0.98)^{*}$ & $-17.12(0.98)^{*}$ \\
\hline \multicolumn{5}{|l|}{ sCD14 } \\
\hline$\leq$ Median & Referent & Referent & Referent & Referent \\
\hline > Median & $-3.19(1.57)^{*}$ & $0.51(3.10)$ & $-1.22(0.66) \#$ & $-1.66(1.31)$ \\
\hline \multicolumn{5}{|l|}{ Haplotypes } \\
\hline GCCA & & Referent & & Referent \\
\hline ATCG & - & $-0.52(2.00)$ & - & $-1.32(0.83)$ \\
\hline GTTG & & $1.81(1.89)$ & & $-0.02(0.80)$ \\
\hline GTCA & & $-2.80(3.32)$ & & $-4.16(1.40)^{*}$ \\
\hline Other & & $12.53(4.78)^{*}$ & & $1.73(2.08)$ \\
\hline \multicolumn{5}{|l|}{ Interaction } \\
\hline GCCA $x \leq$ Median sCD14 $(n=111)$ & & Referent & & Referent \\
\hline ATCG $x>$ Median sCD14 $(n=72)$ & - & $-0.11(2.83)$ & - & $1.39(1.20)$ \\
\hline GTTG x > Median sCD14 $(n=59)$ & & $-6.94(2.85)^{*}$ & & $-1.08(1.21)$ \\
\hline GTCA $x>$ Median sCD14 $(n=24$ & & $0.05(4.45)$ & & 3.54 (1.89)\# \\
\hline Other $x>$ Median sCD14 $(n=6)$ & & $-9.54(6.46)$ & & $-3.78(2.78)$ \\
\hline
\end{tabular}

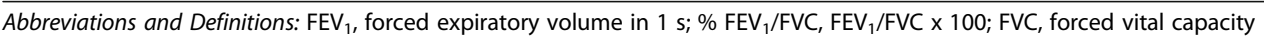

$\wedge$ Haplotypes defined as $-2838 /-1720 /-651 /-260$

${ }^{*} p<0.05, \# \mathrm{p}<0.07$

between CD14 polymorphisms and sCD14 levels decreases from birth to 10 years of age and that this lack of association is paralleled with a significant increase in CD14 methylation. Importantly, CD14 methylation levels were inversely associated with sCD14 levels. Further studies are necessary to understand the impact of agricultural exposure and CD14 methylation on sCD14 levels in this population [38].

There have been a limited number of studies in adults showing an association between CD14 polymorphisms and several lung phenotypes such as asthma and allergy
[39, 40], wheeze [41], pulmonary tuberculosis [42] and pulmonary function [41, 43-45]. While the results of the present study show a weak association between CD14 polymorphisms and lung function, we found a significant interaction between CD14 haplotypes and sCD14 levels on lung function. Many multiplicative interactions have been found with CD14 polymorphisms and environmental exposures. In a study of Dutch farmers and agriculture industry workers, increased environmental exposure to endotoxin in those with the CD14/-1720 T or CD14/-260G allele was associated with lower $\mathrm{FEV}_{1}$ 
values compared to those homozygous for the $\mathrm{C}$ or $\mathrm{A}$ allele [41]. In contrast, in a study of laboratory animal workers, those with high endotoxin exposure and the CD14/-1720C allele had significantly lower lung function than workers with the TT genotype [43]. In another study of adults, pack-years of smoking was found to modify the association between CD14/-260 and lung function $\left(\mathrm{FEV}_{1}\right.$ or $\left.\mathrm{FEV}_{1} / \mathrm{FVC}\right)$ [45]. In this study, the CD14/-260AA genotype was associated with lower lung function in moderate smokers, while heavy smokers with the CC genotype had decreased lung function [45]. These disparate results underscore the complex nature of the CD14 gene and the importance of integrating genetic, epigenetic and environmental exposures for understanding determinants of the outcome.

A strength of this study is that rather than selecting only polymorphisms with known biologic function, our approach involved the use of tagging polymorphisms with the broader goal of capturing the overall polymorphic nature of the gene. Therefore it is possible that the haplotypes examined in this study and shown to interact with sCD14 may have little functional biologic consequence. For instance, the haplotype GTTG was shown to interact with serum sCD14 levels. Each polymorphism in this haplotype is found in the promoter region of the CD14 gene, yet only one locus has been shown to be functional, CD14/-260 [36]. It is possible that the $C D 14 /-2838, C D 14 /-1720$ and $C D 14 /-651$ are not functional but are merely in LD with other regions of the gene. The CD14/-260 polymorphism has been shown to be functional via modifying the transcriptional activity via SP transcription factors, with the A allele having more gene expression than the $G$ allele [36].

To our knowledge, this is the first study to show an association between sCD14 levels, CD14 haplotypes and lung function in an occupationally-exposed population. However the question remains as to whether agricultural exposure plays a role in our findings. Replication of this study in participants without agricultural exposure would be necessary to address this issue. A limitation of using an exposed population is that a "healthy worker effect" may have resulted in bias towards the null, because individuals with respiratory problems may avoid agricultural jobs with the highest exposures. Due to the crosssectional nature of this study, we were unable to account for this type of bias. Furthermore, we were unable to measure LPS in the occupational setting to determine whether the association between sCD14 and lung function was modified by LPS exposure intensity, an area that warrants further study. In addition our population was composed of mostly Caucasian males and additional population studies with other ancestries would be important information.

\section{Conclusions}

In summary, we have shown that levels of sCD14 are inversely associated with pulmonary function and are significantly modified by $C D 14$ haplotypes among those with COPD in this agriculturally-exposed population. Further studies are needed to elucidate the implications and potential effects of higher circulating levels of sCD14 in patients with impaired pulmonary function.

\section{Additional file}

Additional file 1: Interaction of CD14 Haplotypes And Soluble CD14 On Lung Function in Agricultural Workers. (DOC 48 kb)

Additional file 2: Figure S1. Linkage disequilibrium (LD) between 4 SNPs analyzed for CD14. LD values presented as r2×100. (TIF $44 \mathrm{~kb}$ )

\section{Acknowledgments}

We would like to acknowledge the hard work by the study coordinators Robin Zotti-Pierce, Eric Chickris and Kelsey Palm.

\section{Funding}

VA Merit funding for this research (VA Merit Awards to TDL (1I01CX000434-01) and DJR).

Availability of data and materials

The datasets used and/or analyzed during the current study are available from the corresponding author on reasonable request.

\section{Authors' contributions \\ All authors read and approved the final manuscript. TDL: Made substantial contributions to conception and design, acquisition of data, and data analysis and interpretation. TDL wrote the manuscript. LMS: Made substantial contributions to data analysis and interpretation and synthesis of tables and figures for manuscript. AJH: Analyzed all serum samples by ELISA and wrote appropriate Methods for the manuscript. TRM: Was involved in critically revising the manuscript for intellectual content. JLM: Was involved in data acquisition and database synthesis and cleaning. LAWM: Was involved in data acquisition, genotyping and critically revising the manuscript. DJR: Made substantial contributions to conception and design, acquisition of data, and data analysis and interpretation. Was involved in critically revising the manuscript for intellectual content.}

Competing interests

The authors declare that they have no competing interests.

Consent for publication

Not applicable.

Ethics approval and consent to participate

The study was approved by the VA Institutional Review Board (protocol \#315 and 669), and all participants signed a written informed consent document before enrollment.

\section{Publisher's Note}

Springer Nature remains neutral with regard to jurisdictional claims in published maps and institutional affiliations.

\section{Author details}

'Department of Epidemiology, University of Nebraska Medical Center, 985910, Omaha, NE 68198-5910, USA. ²Department of Internal Medicine and Veterans Nebraska Western lowa Healthcare System, Omaha, NE, USA

${ }^{3}$ Department of Biostatistics, University of Nebraska Medical Center, Omaha, NE, USA. ${ }^{4}$ Department of Internal Medicine, University of Nebraska Medical Center, Omaha, NE, USA. 
Received: 28 January 2017 Accepted: 7 March 2017 Published online: 16 March 2017

\section{References}

1. Ziegler-Heitbrock HW, Ulevitch RJ. CD14: cell surface receptor and differentiation marker. Immunol today. 1993;14(3):121-5.

2. Bas S, Gauthier BR, Spenato U, Stingelin S, Gabay C. CD14 is an acute-phase protein. J Immunol. 2004;172(7):4470-9.

3. Bazil V, Horejsi V, Baudys M, Kristofova H, Strominger JL, Kostka W, Hilgert I. Biochemical characterization of a soluble form of the 53-kDa monocyte surface antigen. Eur J Immunol. 1986;16(12):1583-9.

4. Janeway Jr CA. The immune system evolved to discriminate infectious nonself from noninfectious self. Immunol today. 1992:13(1):11-6.

5. Hernandez ML, Harris B, Lay JC, Bromberg PA, Diaz-Sanchez D, Devlin RB, Kleeberger SR, Alexis NE, Peden DB. Comparative airway inflammatory response of normal volunteers to ozone and lipopolysaccharide challenge. Inhal Toxicol. 2010;22(8):648-56

6. Di Gioia M, Zanoni I. Toll-like receptor co-receptors as master regulators of the immune response. Mol Immunol. 2015;63(2):143-52.

7. Kilburn KH. Particles causing lung disease. Environ Health Perspect. 1984;55:97-109.

8. Molocznik A. Qualitative and quantitative analysis of agricultural dust in working environment. Ann Agric Environ Med. 2002;9(1):71-8.

9. Boissy RJ, Romberger DJ, Roughead WA, Weissenburger-Moser L, Poole JA LeVan TD. Shotgun pyrosequencing metagenomic analyses of dusts from swine confinement and grain facilities. PLoS One. 2014;9(4):e95578.

10. Letourneau V, Nehme B, Meriaux A, Masse D, Duchaine C. Impact of production systems on swine confinement buildings bioaerosols. J Occup Environ Hyg. 2010;7(2):94-102.

11. Kirkhorn SR, Garry VF. Agricultural lung diseases. Environ Health Perspect. 2000;108 Suppl 4:705-12.

12. May S, Romberger DJ, Poole JA. Respiratory health effects of large animal farming environments. J Toxicol Environ Health Part B. 2012;15(8):524-41.

13. Alexis N, Eldridge M, Reed W, Bromberg P, Peden DB. CD14-dependent airway neutrophil response to inhaled LPS: role of atopy. J Allergy Clin Immunol. 2001;107(1):31-5.

14. Levan TD, Michel $O$, Dentener M, Thorn J, Vertongen F, Beijer L, Martinez FD. Association between CD14 polymorphisms and serum soluble CD14 levels: effect of atopy and endotoxin inhalation. J Allergy Clin Immunol. 2008;121(2):434-40. e431.

15. Michel O, Nagy AM, Schroeven M, Duchateau J, Neve J, Fondu P, Sergysels R. Dose-response relationship to inhaled endotoxin in normal subjects. Am J Respir Crit Care Med. 1997;156(4 Pt 1):1157-64.

16. Michel O, Duchateau J, Plat G, Cantinieaux B, Hotimsky A, Gerain J, Sergysels R. Blood inflammatory response to inhaled endotoxin in normal subjects. Clin Exper Allergy. 1995;25(1):73-9.

17. Hernandez ML, Mills K, Almond M, Todoric K, Aleman MM, Zhang H, Zhou $H$, Peden DB. IL-1 receptor antagonist reduces endotoxin-induced airway inflammation in healthy volunteers. J Allergy Clin Immunol. 2015;135(2):379-85.

18. Regueiro V, Campos MA, Morey P, Sauleda J, Agusti AG, Garmendia J, Bengoechea JA. Lipopolysaccharide-binding protein and CD14 are increased in the bronchoalveolar lavage fluid of smokers. Eur Respir J. 2009:33(2):273-81.

19. Guerra S, Lohman I, LeVan T, Wright A, Martinez F, Halonen M. The Differential Effect of Genetic Variation on soluble CD14 Levels in Human Plasma and Milk. American Journal of Reproductive Immunology. 2004;52:204-11.

20. LeVan TD, Guerra S, Klimecki W, Vasquez MM, Lohman IC, Martinez FD, Halonen M, Wright AL. The impact of CD14 polymorphisms on the development of soluble CD14 levels during infancy. Genes and immunity. 2006;7(1):77-80

21. Koenig W, Khuseyinova N, Hoffmann MM, Marz W, Frohlich M, Hoffmeister A, Brenner H, Rothenbacher D. CD14 C(-260) T polymorphism, plasma levels of the soluble endotoxin receptor CD14, their association with chronic infections and risk of stable coronary artery disease. J Am Coll Cardiol. 2002:40(1):34-42.

22. Raunio T, Knuuttila M, Karttunen R, Vainio O, Tervonen T. Serum sCD14, polymorphism of CD14(-260) and periodontal infection. Oral Dis. 2009;15(7):484-9.
23. Alavi-Naini R, Salimi S, Sharifi-Mood B, Davoodikia AA, Moody B, Naghavi A. Association between the CD14 gene C-159 T polymorphism and serum soluble CD14 with pulmonary tuberculosis. Int J Tuberc Lung Dis. 2012;16(10):1383-7.

24. Control CfD: Adult Tobacco Use Information. 2015. https://www.cdc.gov/ nchs/nhis/tobacco/tobacco glossary.htm.

25. Global Strategy for Diagnosis, Management and Prevention of COPD. 2014.

26. Brazzale DJ, Hall GL, Pretto JJ. Effects of adopting the new global lung function initiative 2012 reference equations on the interpretation of spirometry. Resp Int Rev Thorac Dis. 2013;86(3):183-9.

27. Carlson CS, Eberle MA, Rieder MJ, Yi Q, Kruglyak L, Nickerson DA. Selecting a maximally informative set of single-nucleotide polymorphisms for association analyses using linkage disequilibrium. Am J Human Genet. 2004;74(1):106-20

28. Affairs USDoV: National survey of veterans. 2010. Available from: http:// www.virec.research.va.gov

29. Anas A, van der Poll T, de Vos AF. Role of CD14 in lung inflammation and infection. Critical Care. 2010;14(2):209.

30. Nicu EA, Laine ML, Morre SA, Van der Velden U, Loos BG. Soluble CD14 in periodontitis. Innate Immun. 2009;15(2):121-8.

31. Zhang $A Q$, Yue $C L, G u$ W, Du J, Wang HY, Jiang J. Association between CD14 promoter $-159 \mathrm{C} / \mathrm{T}$ polymorphism and the risk of sepsis and mortality: a systematic review and meta-analysis. PLoS One. 2013;8(8):e71237.

32. Mikuls TR, LeVan TD, Sayles H, Yu F, Caplan L, Cannon GW, Kerr GS, Reimold AM, Johnson DS, Thiele GM. Soluble CD14 and CD14 polymorphisms in rheumatoid arthritis. J Rheumatol. 2011:38(12):2509-16.

33. Zhao L, Bracken MB. Association of CD14-260 (-159) C > T and asthma: a systematic review and meta-analysis. BMC Med Genet. 2011;12:93.

34. LeVan TD, Von Essen S, Romberger DJ, Lambert GP, Martinez FD, Vasquez MM, Merchant JA. Polymorphisms in the CD14 gene associated with pulmonary function in farmers. Am J Respir Crit Care Med. 2005;171(7):773-9.

35. Baldini M, Lohman IC, Halonen M, Erickson RP, Holt PG, Martinez FD. A Polymorphism* in the $5^{\prime}$ flanking region of the CD14 gene is associated with circulating soluble CD14 levels and with total serum immunoglobulin E. Am J Respir Cell Mol Biol. 1999;20(5):976-83.

36. LeVan TD, Bloom JW, Bailey TJ, Karp CL, Halonen M, Martinez FD, Vercelli D. A common single nucleotide polymorphism in the CD14 promoter decreases the affinity of $\mathrm{Sp}$ protein binding and enhances transcriptional activity. J Immunol. 2001;167(10):5838-44.

37. Liang XH, Cheung W, Heng CK, Liu JJ, Li CW, Lim B, de Wang Y. CD14 promoter polymorphisms have no functional significance and are not associated with atopic phenotypes. Pharmacogenet Genomics. 2006;16(4):229-36

38. Munthe-Kaas MC, Torjussen TM, Gervin K, Lodrup Carlsen KC, Carlsen KH, Granum B, Hjorthaug HS, Undlien D, Lyle R. CD14 polymorphisms and serum CD14 levels through childhood: a role for gene methylation? J Allergy Clin Immunol. 2010;125(6):1361-8.

39. Smit LA, Siroux V, Bouzigon E, Oryszczyn MP, Lathrop M, Demenais F, Kauffmann F. CD14 and toll-like receptor gene polymorphisms, country living, and asthma in adults. Am J Respir Crit Care Med. 2009;179(5):363-8.

40. Sahin F, Yildiz P, Kuskucu A, Kuskucu MA, Karaca N, Midilli K. The effect of CD14 and TLR4 gene polymorphisms on asthma phenotypes in adult Turkish asthma patients: a genetic study. BMC Pulm Med. 2014;14:20.

41. Smit LA, Heederik D, Doekes G, Koppelman GH, Bottema RW, Postma DS, Wouters IM. Endotoxin exposure, CD14 and wheeze among farmers: a gene-environment interaction. Occup Environ Med. 2011;68(11):826-31.

42. Zhao J, Lin G, Zhang WH, Ge M, Zhang Y. Contribution of CD14-159C/T polymorphism to tuberculosis susceptibility: a meta-analysis. Int J Tuberc Lung Dis. 2013:17(11):1472-8.

43. Pacheco KA, Rose CS, Silveira LJ, Van Dyke MV, Goelz K, MacPhail K, Maier LA. Gene-environment interactions influence airways function in laboratory animal workers. J Allergy Clin Immunol. 2010;126(2):232-40.

44. Bakolis I, Doekes G, Heinrich J, Zock JP, Heederik D, Kogevinas M, Guerra S, Norback D, Ramasamy A, Nevalainen A, et al. Respiratory health and endotoxin: associations and modification by CD14/-260 genotype. Eur Respir J. 2012;39(3):573-81.

45. Zhou H, Alexis NE, Almond M, Donohue J, Laforce C, Bromberg PA, Peden DB. Influence of C-159 T SNP of the CD14 gene promoter on lung function in smokers. Respir Med. 2009;103:1358. 